\title{
Quality and yield of yam tubers cultivated with green manure in the Northeastern Brazil
}

\author{
Marlon Da Silva Garrido ${ }^{*}$, Ana Cristina Fermino Soares ${ }^{2}$ \\ Rômulo Simões Cezar Menezes ${ }^{3}$, Everardo Valadares de Sá Barreto Sampaio33, \\ Erik Micael da Silva Souza', Bruno Lopes do Nascimento Macedo' \\ ${ }^{1}$ Federal University of São Francisco Valley, Juazeiro Brazil. \\ ${ }^{2}$ Federal University of Recôncavo Bahia, Cruz das Almas, Brazil. \\ ${ }^{3}$ Federal University of Pernambuco, Recife, Brazil. \\ *Corresponding author, e-mail: marlon.garrido@univasf.edu.br
}

\begin{abstract}
Yam (Dioscorea cayennensis Lam.) is a promising crop for small growers in the Northeast of Brazil, but productivities are limited due to low fertilization rates. Green manure could be an alternative due to its low cost and high availability. However, there is little information available regarding the effects of green manures on the productivity of yam. The quality and yield of yam tubers, "da costa" variety, were evaluated under application of three different green manures and a control treatment: 1) yam intercropped with sunn hemp (Crotalaria juncea L.); 2) yam intercropped with pigeon pea (Cajanus cajan L.); 3) yam intercropped with a combination of sunn hemp and pigeon pea; and 4) conventional yam crop system. The experiment was laid out in a randomized block design, with four repetitions. The data was submitted to analysis of variance and averages compared by Tukey's test at $5 \%$. Percentage values were transformed into arc sen $(x / 100)^{0.5}$. Sunn hemp and the combination of sunn hemp with pigeon pea produced the highest green manure biomasses (3.8 and 3.6 † DM ha ', respectively) versus $2.1+\mathrm{ha}^{-1}$ with the use of only pigeon pea. However, the $\mathrm{N}$ concentration was higher in pigeon pea than in sunn hemp $\left(26\right.$ and $\left.16 \mathrm{~g} \mathrm{~kg}^{-1}\right)$. Intercropping with pigeon pea led to the highest yield for total tubers $\left(33.1 \mathrm{tha}^{-1}\right)$, for market quality $\left(32.2+\mathrm{ha}^{-1}\right)$ and standard exportation quality tubers $\left(23.0 \mathrm{tha}^{-1}\right)$.
\end{abstract}

Keywords: Cajanus cajan, Crotalaria juncea, Dioscorea cayennensis Lam., sunn hemp, pigeon pea

\section{Introduction}

Yam (Dioscorea cayennensis Lam.) is a promising alternative crop for small and medium farms in the Brazilian Northeastern region, due to its great potential for external and internal markets (Garrido et al., 2003). In the last decade, the yam agribusiness had an significant increase, contributing to the expansion of cultivated areas (Mendes et al., 2005). Brazil is the main South American producer, with an annual crop of about 245 thousand tons from 25.5 thousand hectares (FAOSTAT, 2013), most of them in the Northeastern region. However, the average productivity is low $\left(9.6 \mathrm{tha}^{-1}\right)$ as a result of the low level of technology employed in its management a fact also observed in other countries, such as Jamaica (Sue and Wickham, 1998). Using improved technology, productivities as high as 46 $\dagger$ ha $^{-1}$ have been obtained in Brazil (Herediaz et al., 2000).

Nutrient deficiency is a general cause of low productivities in the crop (Diby, 2009), but fertilizer applications are limited in small and medium size farms, due to their high costs and low capital availability (Garrido et al., 2003; Saab \& Paula, 2008). A viable alternative is the use of green manures, which can be intercropped with yam and are known to restore physical, chemical and biological characteristics of the soil in agricultural lands (Ferreira, 2012). Using legume 
species as green manure may also contribute with atmospheric $\mathrm{N}_{2}$ fixation and enhance soil $\mathrm{N}$ availability (Faria et al., 2007; Herridge et al., 2008). Specifically in yam crops, green manures may favor seed germination and minimize plant stress in hotter periods of the year (Buderman, 1989).

In cropping systems with green manures, the choice of species that are well adapted to the climatic conditions of each region is fundamental. Pigeon pea (Cajanus cajan L.) and crotalaria or sunnhemp (Crotalaria juncea L.) are two of the most planted species under conditions similar to those of Northeastern Brazil because of their great biomass production potential (Amabile, 2000). However, they have not been scientifically tested in yam cropping systems in the region. Therefore, this study was set up to evaluate the effects of pigeon pea and sunnhemp as green manures on the productivity and quality of yam tubers.

\section{Material and Methods}

The experiment was conducted at Sitio São Carlos, municipality of Maragojipe, Bahia, Brazil (12.79907 S and 39.03992 W of Greenwich), under rain fed conditions. The mean annual rainfall of the region is $1,500 \mathrm{~mm}$, well distributed throughout the year, and the mean annual temperature is about $26^{\circ} \mathrm{C}$, with little monthly variation. The soil is a Red Yellow Latosol, with the following chemical characteristics: $\mathrm{pH}_{\mathrm{H} 2 \mathrm{O}}=$ 4.9, Mehlich extractable $\mathrm{P}=1 \mathrm{mg}^{-\mathrm{dm}^{-3}}, \mathrm{~K}=51$ $\mathrm{mg} \cdot \mathrm{dm}^{-3}, \mathrm{Ca}=0.75 \mathrm{cmol}_{\mathrm{c}} \cdot \mathrm{dm}^{-3}, \mathrm{Mg}=0.45 \mathrm{cmol}_{\mathrm{c}}$. $\mathrm{dm}^{-3}, \mathrm{Al}=0.2 \mathrm{cmol}_{\mathrm{c}} \cdot \mathrm{dm}^{-3}, \mathrm{Na}=0.008 \mathrm{cmol}_{\mathrm{c}} \cdot \mathrm{dm}^{-3}$ and organic matter $=17 \mathrm{~g} \cdot \mathrm{kg}^{-1}$. The experiment consisted of four treatments: T1- conventional yam planting (sole crop) fertilized only with cattle manure; T2- yam intercropped with sunnhemp (Crotalaria juncea L.), IAC-KR I variety; T3- yam intercropped with pigeon pea (Cajanus cajan L.), fava larga variety; and T4- yam intercropped with a combination of sunn hemp and pigeon pea. The experiment was laid out as a randomized block design, with four replications. Before planting, 12 t ha-1 of cattle manure were broadcasted in the field and ridges $0.5 \mathrm{~m}$ high and $1.2 \mathrm{~m}$ apart were made. Each experimental plot consisted of four ridges, each one $4.8 \mathrm{~m}$ long, and yam seeds were planted on the top of the ridges with a spacing of $0.4 \mathrm{~m}$, corresponding to a total density slightly over 20 thousand plants $\mathrm{ha}^{-1}$. The two external ridges and the two extreme plants in each central ridge of each plot were considered as border areas. The seeds consisted of middle and lower tuber portions, the upper portions being discarded due to their different development (precocious germination).

One month later, the green manure species were sowed in two rows, $0.25 \mathrm{~m}$ apart, between each ridge, at a density of 10 plants per linear meter of row. The seeds were inoculated with Rhizobium specific for $C$. juncea and for $C$. cajan, obtained from Embrapa Agrobiologia, in Rio de Janeiro. After 60 days, the green manure plants were cut and incorporated manually into the soil using hoes to a depth of approximately $0.20 \mathrm{~m}$. To quantify their aboveground biomass production the green manure, two one linear meter samples were collected from each plot. The samples were oven dried at $65^{\circ} \mathrm{C}$ until constant weight, ground, digested with a sulfuric and nitroperchloric mixture and analyzed following the methodology described by Vitti et al. (2000). Nitrogen was determined by the Kjeldahl method; phosphorous by colorimetry; $\mathrm{Ca}, \mathrm{Mg}, \mathrm{Cu}, \mathrm{Fe}$ and $\mathrm{Mn}$ by atomic absorption; and $\mathrm{K}$ by flame photometry.

The yam was harvested in November. Fresh weight, length and diameter of each tuber were determined and its quality was rated based on its weight and on a visual classification (Santos, 1996).

The data was submitted to analysis of variance and averages compared by the Tukey test at $5 \%$ probability level. Percentage values were transformed into arc sen $(x / 100)^{0.5}$. Analyses were done using SISVAR (Ferreira, 2011).

\section{Results and Discussion}

Green manure productivities (Table 1) were greater in the treatments with sunnhemp, alone $\left(3.8+\mathrm{ha}^{-1}\right)$ or combined with pigeon pea $\left(3.6 \mathrm{tha}^{-1}\right)$, than in the treatment with pigeon pea alone $\left(2.1+\mathrm{ha}^{-1}\right)$. Sunnhemp and pigeon pea aboveground biomass productivities may vary from 0.5 to 17 t ha $^{-1}$ (Blaise et al., 2005a; Perin et al., 2006; Prellwitz \& Coelho, 2011; Pereira, 2012; 
Ambrosano et al., 2013). Intercropping usually results in biomasses in the lower part of this range (Blaise et al., 2005a; Dantas, 2015) because of lower plant densities and competition with the main crop. The effect of competition may be enhanced when the green manure crops are planted after the main crop (Blaise et al. 2005a; Ambrosano et al, 2013), as in the present experiment, in which they were planted one month after the yam plants. The period of growth is another important variable controlling productivities of green manures. Pigeon pea has a slower initial growth than sunnhemp (Blaise et al, 2005b; Dantas, 2015).

The greater biomass of sunnhemp treatments contributed to their higher nutrient recycling than that of pigeon pea, in spite of higher dry matter concentrations of $\mathrm{N}$ and $\mathrm{P}$ in pigeon pea (Table 1). The contribution of nitrogen was particularly important, part of which may have come from symbiotic $\mathrm{N}_{2}$ fixation (Perin et al. 2006, Espana et al. 2006; Faria et al, 2007) which could lead to net increases in soil $\mathrm{N}$ availability. The highest $\mathrm{N}$ contribution came from the pigeon pea and sunnhemp treatment (75 $\mathrm{kg} \mathrm{N} \mathrm{ha-1),} \mathrm{probably} \mathrm{by} \mathrm{the} \mathrm{combination} \mathrm{of} \mathrm{the}$ greater biomass of sunnhemp and the greater $\mathrm{N}$ concentration of pigeon pea $\left(26 \mathrm{~g} \mathrm{~N} \mathrm{~kg}^{-1}\right)$, but the only significant difference was in relation to the pigeon pea treatment contribution (55 $\mathrm{kg} \mathrm{ha}^{-1}$ ). Contributions much higher than those have been reported, usually as a direct result of higher biomass productions (Perin et al., 2006; Ambrosano et al. 2013). However, higher concentrations can also account for part of the higher contributions (Blaise et al. 2005, Perin et al. 2006; Carneiro, 2008; Prellwitz \& Coelho, 2011), especially comparing to the low concentration in sunnhemp $\left(16 \mathrm{~g} \mathrm{~kg}^{-1}\right)$.

Table 1. Dry matter yield and nutrient contents per area and mass of different green manure plants intercropped with yam. Values with the same letter in each column do not differ by the Tukey's test at $5 \%$.

\begin{tabular}{|c|c|c|c|c|c|c|c|c|c|}
\hline \multirow[t]{2}{*}{ Treatments } & Yield & $\mathrm{N}$ & $P$ & K & $\mathrm{Ca}$ & $\mathrm{Mg}$ & $\mathrm{Cu}$ & $M n$ & $\mathrm{Fe}$ \\
\hline & (t ha') & \multicolumn{5}{|c|}{ - } & \multicolumn{3}{|c|}{--------(g ha'-1)------- } \\
\hline \multicolumn{10}{|c|}{ Nutrient contents } \\
\hline Sunn hemp & $3.8 a$ & $62.8 \mathrm{ab}$ & $10.5 a$ & $65.8 a$ & $39.1 a$ & $15.8 \mathrm{a}$ & $92.08 \mathrm{~b}$ & $581.4 a b$ & $1,536.4 \mathrm{~b}$ \\
\hline Pigeon pea & $2.1 \mathrm{~b}$ & $54.8 \mathrm{~b}$ & $7.5 a$ & $31.5 b$ & $15.1 \mathrm{C}$ & $7.28 b$ & $53.69 c$ & $359.1 b$ & $574.7 c$ \\
\hline Pigeon pea +Sunn hemp & $3.6 a$ & $75.5 a$ & $12.0 a$ & $70.8 a$ & $28.7 b$ & $10.7 a b$ & $118.5 a$ & $795.9 a$ & $2,182.8 \mathrm{a}$ \\
\hline \multirow[t]{3}{*}{$C \vee(\%)$} & 12.8 & 12.2 & 22.3 & 10.8 & 21.7 & 16.2 & 9.1 & 48.9 & 23.7 \\
\hline & & \multirow{2}{*}{\multicolumn{8}{|c|}{ Nutrient concentrations }} \\
\hline & & & & & & & & & \\
\hline Sunn hemp & & $16.5 c$ & $2.8 b$ & $17.3 a$ & $10.3 a$ & $4.2 a$ & $24 b$ & $153 b$ & $404 b$ \\
\hline Pigeon pea & & $26.1 a$ & $3.6 a$ & $15.0 a$ & $7.2 b$ & $3.5 a b$ & $26 b$ & $171 b$ & $274 c$ \\
\hline Pigeon pea +Sunn hemp & & $21.0 \mathrm{~b}$ & $3.3 a$ & $20.0 a$ & $8.0 b$ & $3.0 \mathrm{~b}$ & $33 a$ & $221 a$ & $606 a$ \\
\hline$C V(\%)$ & & 13.1 & 9.4 & 21.3 & 11.3 & 14.2 & 16.1 & 13.3 & 11.9 \\
\hline
\end{tabular}

Yam tuber productivities (Table 2) were higher in the pigeon pea treatment $(33.1 \mathrm{Mg} \mathrm{ha}$ 1) followed by the combination of pigeon pea and sunnhemp (29.5 $\left.\mathrm{Mg} \mathrm{ha}^{-1}\right)$. Intercropping with sunnhemp alone resulted in a productivity of yam tubers $\left(20.3 \mathrm{Mg} \mathrm{ha}^{-1}\right)$ similar to that obtained in the conventional cropping, without green manure (19.4 $\left.\mathrm{Mg} \mathrm{ha}^{-1}\right)$. When evaluating yam production, it is important to consider not only the quantity of tubers but also their commercial quality. In the internal market, they are classified as: standard, deformed and seed tubers (Santos 1996). This classification is based on their format and weight and the first two classes are considered as commercial tubers while the last one refers to small tubers only used by farmers as seeds of their future crops. The proportion of commercial tubers, especially standard ones, in relation to the total tuber weight, were highest in the pigeon pea treatment (97 and 69\%) and lowest in the conventional cropping (81 and 30\%) and this difference is magnified if the absolute weights are considered because of the higher total weight of the pigeon pea treatment (Table 2).

Considering the number of tubers in each classification, the proportions of seed tubers increased in all treatments because of their lower 
unitary weight than those of the standard and deformed tubers (Table 3). By this criterion, about half of the tubers produced in the conventional treatment did not reach commercial class, a proportion similar to that reported by Garrido et al. (2003) for the production of the state of Bahia, in Brazil. In contrast, in the pigeon pea treatment only $12 \%$ of the tubers had no commercial value. The differences among treatments were more related to the format of the tubers than to their size, since there were no significant differences regarding their lengths and diameters (Table 3).

Table 2. Weight of yam tubers, according to their commercial classification (proportions in brackets), produced under different green manure treatments. Values with the same letter in each column do not differ by the Tukey's test at $5 \%$.

\begin{tabular}{ccccc}
\hline & Standard & Deformed & Seed & Total \\
Treatments & $----------------------~$ & $\left(\mathrm{~h} \mathrm{ha}^{-1}\right)$ & \\
\hline Conventional & $6.0 \mathrm{c}$ & $10.4 \mathrm{~b}$ & $3.9 \mathrm{a}$ & $20.3 \mathrm{c}$ \\
Pigeon pea & $23.0 \mathrm{a}$ & $9.3 \mathrm{~b}$ & $0.9 \mathrm{c}$ & $33.1 \mathrm{a}$ \\
Sunn hemp & $7.8 \mathrm{c}$ & $8.6 \mathrm{~b}$ & $3.0 \mathrm{~b}$ & $19.4 \mathrm{c}$ \\
Pigeon pea + Sunn hemp & $13.8 \mathrm{~b}$ & $13.4 \mathrm{a}$ & $2.3 \mathrm{~b}$ & $29.5 \mathrm{~b}$ \\
CV (\%) & 16.8 & 11.4 & 16.2 & 11.7 \\
\hline
\end{tabular}

Table 3. Proportions in different commercial classes of the total number of tubers produced under different green manure treatments and average characteristics of unitary tubers. Values with the same letter in each column and tuber class do not differ by the Tukey's test at $5 \%$.

\begin{tabular}{|c|c|c|c|c|}
\hline Treatments & $\begin{array}{c}\text { Numbers of Tubers } \\
(\%)\end{array}$ & $\begin{array}{c}\text { Fresh weight } \\
(\mathrm{kg})\end{array}$ & \multicolumn{2}{|c|}{ - } \\
\hline & & Standard & & \\
\hline Conventional & $26.7 c$ & $1.410 \mathrm{c}$ & $36.3 a$ & $7.45 a$ \\
\hline Pigeon Pea & $70.0 a$ & $2.050 a$ & $36.2 a$ & $8.74 a$ \\
\hline Sunn hemp & $30.7 c$ & $1.590 \mathrm{bc}$ & $36.8 a$ & $8.27 a$ \\
\hline Pigeon pea + Sunn hemp & $50.3 b$ & $1.710 \mathrm{~b}$ & $40.23 a$ & $7.83 a$ \\
\hline CV (\%) & 18.9 & $\begin{array}{c}18.2 \\
\text { Deformed }\end{array}$ & 16.6 & 13.9 \\
\hline Conventional & $20.3 b c$ & $3.190 \mathrm{~b}$ & $39.8 a$ & $15.5 a$ \\
\hline Pigeon Pea & $18.0 \mathrm{c}$ & $3.225 a b$ & $40.1 a$ & $15.4 a$ \\
\hline Sunn hemp & $28.3 a$ & $1.890 \mathrm{c}$ & $36.7 a$ & $14.6 a$ \\
\hline Pigeon pea + Sunn hemp & $23.0 \mathrm{~b}$ & $3.654 a$ & $39.3 a$ & $14.8 \mathrm{a}$ \\
\hline$C \vee(\%)$ & 11.8 & 22.3 & 10.4 & 20.4 \\
\hline Conventional & $53.0 a$ & $0.464 a$ & $16.3 a$ & $4.8 a$ \\
\hline Pigeon Pea & $12.0 d$ & $0.463 a$ & $18.7 a$ & $5.1 a$ \\
\hline Sunn hemp & $41.0 \mathrm{~b}$ & $0.455 a$ & $16.7 a$ & $5.6 a$ \\
\hline Pigeon pea + Sunn hemp & $26.7 c$ & $0.536 a$ & $18.3 a$ & $6.2 a$ \\
\hline CV (\%) & 16.4 & 14.7 & 15.2 & 26.3 \\
\hline
\end{tabular}

The greater yam production response to the pigeon pea intercropping than to sunnhemp can be credited to its lower competition level and/or to its higher $\mathrm{N}$ and $\mathrm{P}$ concentrations. Sunnhemp has an erect habit and grows faster than pigeon pea (Blaise et al., 2005ab, Dantas, 2015). Its plants reached more than $2 \mathrm{~m}$ height while those of pigeon pea were only slightly above $0.5 \mathrm{~m}$. Pigeon pea also develops a deeper root system, being able to explore a larger soil volume. Therefore, in the present study, sunnhemp may have competed to a greater extent with the yam crop for light, water and nutrients.

The faster growth of sunnhemp may have also resulted in a material richer in lignin and cellulose and lower in easily mineralizable $\mathrm{N}$. Its C:N ratio was probably close to $25: 1$ while that of pigeon pea was close to 15:1 (Carneiro, 2008). Therefore, its material may even have caused an initial net $\mathrm{N}$ immobilization while that of pigeon pea may have started mineralizing as soon as it was incorporated into the soil. This difference may have resulted in a nitrogen release not in synchrony with the yam plant demands or even in a lower final sunn hemp residue $\mathrm{N}$ 
availability. It has been reported that sunnhemp residues decomposes very fast, with a half-life of $\mathrm{N}$ release of two to three weeks (Perin et al., 2006), transferring up to $25 \%$ of their $N$ to the main crop (Fosu et al., 2003), but in all these cases the material was richer in $\mathrm{N}$ than that obtained in the present experiment. In a study where sunnhemp presented a low concentration of $\mathrm{N}$ (17 $\mathrm{g} \mathrm{kg}^{-1}$ ), a subsequent maize crop produced less than following mucuna (Mucuna aterrima, $30 \mathrm{~g} \mathrm{~kg}^{-1}$ ) in spite of a three times higher total $\mathrm{N}$ incorporation by sunnhemp. In a comparison of the effects on soil characteristics of pigeon pea and sunnhemp incorporations (Carneiro, 2008), mineral $\mathrm{N}$ concentrations increased faster with pigeon pea material than with sunnhemp in spite of coming from older plants (close to five and three months for pigeon pea and sunnhemp, respectively). In the present experiment, the bulk of sunnhemp mineralization was probably delayed for more than three months after its incorporation, occurring after the peak of yam nutrient absorption, when tuber growth begins, about 120 to 150 days after its planting (Santos, 1996).

The immobilization and release of other nutrients may also have been important, especially $P$ which was very low in the soil. $P$ concentration (Table 1) in pigeon pea $(3.6 \mathrm{~g} \mathrm{~kg}$ 1) was higher than in sunnhemp $\left(2.8 \mathrm{~g} \mathrm{~kg}^{-1}\right)$ and above the critical level for mineralization (2 to $3 \mathrm{~g}$ $\mathrm{kg}^{-1}$ ) established by Singh et al. (1992). However, the subject has received much less attention than $\mathrm{N}$, rendering it difficult to discuss, particularly because concentrations of $P$ in green manure biomass are seldom informed in the literature dealing with the use of green manures. Both higher and lower concentrations have been reported (Blaise et al. 2005a, Teixeira et al. 2008).

\section{Conclusions}

Tuber productivity and quality were higher when yam was intercropped with pigeon pea than with sunnhemp or a combination of both green manure species, in spite of the higher biomass production and nutrient contents of sunnhemp.

\section{References}

Ambrosano, E.J., Cantarella, H., Rossi, F., Schammass, E.A., Silva, E.C., Ambrosano, G.M.B., Dias, F.L.F., Trivelin, P.C.O., Muraoka, T. 2013. Desempenho de adubos verdes e da primeira soqueira de cana-de-açúcar em cultivo orgânico. Revista Brasileira de Agroecologia 8: 80-90.

Blaise, D., Bonde, A.N., Chaudhary, R.S. 2005 a. Nutrient uptake and balance of cotton + pigeonpea strip intercropping on rainfed Vertisols of central India. Nutrient Cycling in Agroecosystems 73: 135-145.

Blaise, D., Majumdar, G., Tekale, K.U. $2005 b$. On-farm evaluation of fertilizer application and conservation tillage on productivity of cotton + pigeonpea strip intercropping on rainfed Vertisols of central India. Soil Tillage Research 84: 108-117.

Budelman, A. 1989. Effect of the application of the leaf mulch of Gliricidia sepium on early development, leaf nutrient content and tuber yields of water yam (Dioscorea alata). Agroforestry Systems 8: 243-256.

Carneiro, M.A.C., Cordeiro, M.A.S., Assis, P.C.R., Moraes, E.S., Pereira, H.S., Paulino, H.B., Souza, E.D. 2008. Produção de fitomassa de diferentes espécies de cobertura e suas alterações na atividade microbiana de solo de cerrado. Bragantia 67: 455-462.

Dantas, R.A., Carmona, R., Carvalho, A.M., Rein, T.A., Malaquias, J.V., Júnior, J.D.G.S. 2015. Produção de matéria seca e controle de plantas daninhas por leguminosas consorciadas com cana-de-açúcar em cultivo orgânico. Pesquisa Agropecuária Brasileira [online] 50: 681-689.

Diby, L.N., Hgaza, V.K., Tie, T.B., Assa, A., Carsky, R., Girardin, O., Frossard, E. 2009. Productivity of yams (Dioscorea spp.) as affected by soil fertility. Journal of Animal \& Plant Sciences 5: 494 -506.

Espana, M., Cabrera-bisbal, E., Lopez, M. 2006. Study of nitrogen fixation by tropical legumes in acid soil from Venezuelan savannas using N-15. Interciencia 31: 197-201.

FAOSTAT. Food and Agriculture Organization of the United Nations 2013 http://faostat3.fao. org/<Accessed on November 20, 2015>

Faria, C.M.B., Soares, J.M., Costa, N.D., Faria, A.F. 2007. Atributos químicos de um argissolo e rendimento de melão mediante o uso de adubos verdes, calagem e adubação. Revista brasileira de Ciência do Solo 31: 299-307.

Ferreira, D.F. 2011 . Sisvar: a computer statistical analysis system. Ciência Agrotecnologia [online] 35: 1039-1042. 
Ferreira, L.E., Souza, E.P., Chaves, A.F. 2012. Adubação verde e seu efeito sobre os atributos do solo. Revista Verde de Agroecologia e Desenvolvimento Sustentável 7: 33-38.

Garrido, M.S., Soares, A.C.F., Mendes, L.N., Perez, J.O. 2003. O estudo de novas tecnologias para a produção do inhame (Dioscorea cayennensis Lam.) no Estado da Bahia. Revista Bahia Agrícola 6: 19-22.

Herediaz, N.A., Vieira, M.C., Minuzzi, A. 2000. Produção de cará (Dioscorea sp.) em diferentes densidades de plantio. Ciência Agrotecnologia 24: 387-391.

Herridge, D.F., Peoples, M.B., Boddey, R.M. 2008. Global inputs of biological nitrogen fixation in agricultural systems. Plant Soil 31 1: 1-18.

Mendes, L.N., Garrido, M.S., Olalde, A.R. 2005. Agricultura familiar no Recôncavo baiano: O caso dos pequenos produtores de inhame (Dioscorea cayennensis Lam.) do município de Maragojipe- BA. Oikos 16: 29-41.

Pereira, G.A.M., Silva, D.V., Braga, R.R., Carvalho, F.P., Ferreira, E.A., Santos, J.B. 2012. Fitomassa de adubos verdes e cobertura do solo na região do Alto Vale do Jequitinhonha, Minas Gerais. Revista Agroambiente [online] 6: 110-116.

Perin, A., Santos, R.H.S., Urquiaga, S.S., Cecon, P.R., Guerra, J.G.M., Freitas, G.B. 2006. Sunnhemp and millet as green manure for tropical maize production. Scientia Agricola 63: 453-459.

Prellwitz, W.P.V., Coelho, F.C. 2011 . Produtividade de colmos, índice de área foliar e acúmulo de $\mathrm{N}$ na soca de cana-de-açúcar em cultivo intercalar com Crotalaria juncea L. Revista Ceres 58: 773-780.

Saab, A.A., Paula, R.A. 2008. O mercado de fertilizantes no Brasil: Diagnóstico e propostas de políticas. Revista de Política Agrícola 1: 5-22

Santos, E.S. 1996. Inhame (Dioscorea spp) aspectos básicos da cultura. EMEPA-PB/Sebrae, João Pessoa, Brasil. 158 p.

Sue, H.C., Wickham, L.D. 1998. Improving traditional yam production systems: The case of yellow yams in Jamaica. Tropical Agriculture 75: 252-256.

Teixeira, C.M., Carvalho, G.J., Andrade, M.J.B., Furtini Neto, A.E. 2008. Fitomassa, teor e acúmulo de micronutrientes do milheto, feijão-de porcoe guandu-anão, em cultivo solteiro e consorciado. Acta Scientiarum. Agronomy 30: 533-538.

Vitti, G.C., Ferreira, A.C., Braga, G., Gomes, M.T.B. 2000. Método de análise de elementos em material vegetal. ESALQ, Piracicaba, Brasil. 28 p. 